\title{
A Fluorohydrogenate lonic Liquid Fuel Cell Operating Without Humidification
}

\section{$\operatorname{AUTHOR}(S)$ :}

Hagiwara, Rika; Nohira, Toshiyuki; Matsumoto, Kazuhiko; Tamba, Yuko

\section{CITATION:}

Hagiwara, Rika ... [et al]. A Fluo rohydrogenate Ionic Liquid Fuel Cell Operating Without Humidification. Electrochemical and Solid-State Letters 2005, 8(4): A231-A233

\section{ISSUE DATE:}

2005-03-01

URL:

http://hdl.handle.net/2433/251197

\section{RIGHT:}

(c) The Electrochemical Society, Inc. 2005. All rights reserved. Except as provided under U.S. copyright law, this work may not be reproduced, resold, distributed, or modified without the express permission of The Electrochemical Society (ECS). The archival version of this work was published in [doi:10.1149/1.1870672 'Electrochemical and Solid-State Letters' volume 8, issue 4,A231-A233].; この論文は出版社版でありません。引用の際には出版社版をご確認ご利用くだ さい。; This is not the published version. Please cite only the published version. 


\section{A fluorohydrogenate ionic liquid fuel cell operating without}

\section{humidification}

Rika Hagiwara, ${ }^{z^{*}}$ Toshiyuki Nohira, Kazuhiko Matsumoto, Yuko Tamba

Graduate School of Energy Science, Kyoto University, Yoshida, Sakyo-ku, Kyoto

606-8501, Japan

* Electrochemical Society Active Member

z E-mail: hagiwara@energy.kyoto-u.ac.jp; Tel: $\quad+81-75-753-5822 ; \quad$ Fax:

$+81-75-753-5906$

Keyword: Room temperature ionic liquid, Room temperature molten salt, Fuel cell 


\section{Abstract}

A fuel cell operating without humidification and driven by hydrogen transfer via fluorohydrogenate anions, $(\mathrm{HF})_{n} \mathrm{~F}^{-}$, has been constructed using a room temperature molten salt, 1-ethyl-3-methylimidazolium fluorohydrogenates, EMIm(HF) ${ }_{n} \mathrm{~F}$. The open circuit voltage was approximately $1.1 \mathrm{~V}$ under the flow of hydrogen and oxygen gas at $298 \mathrm{~K}$. Polarization behaviors of the $\mathrm{H}_{2}$ anode and $\mathrm{O}_{2}$ cathode in $\mathrm{EMIm}(\mathrm{HF})_{2.3} \mathrm{~F}$ have revealed satisfactory performances as a fuel cell electrolyte. $\mathrm{EMIm}(\mathrm{HF})_{1.3 \mathrm{~F}}$, which is thermally more stable than $\mathrm{EMIm}(\mathrm{HF})_{2.3} \mathrm{~F}$ and does not liberate $\mathrm{HF}$ even at $373 \mathrm{~K}$, exhibits significantly improved polarization behavior by the elevation of the operation temperature. 


\section{Introduction}

Polymer electrolyte fuel cells (PEFCs) using proton exchange membranes now appear to be the best candidates for large-scale commercialization of fuel cells and are being extensively studied. However, the proton exchange membranes used for the electrolytes need humidification for operation without losing ionic conduction, with their practical operation temperatures being limited to under $353 \mathrm{~K}$. Operation at somewhat higher temperatures without humidification is required for applications of the fuel cells in vehicles in order to reduce the sizes of radiators for cooling the cells. Moreover, elevated temperature operation increases the catalytic activity of the gas electrodes. In addition, elevation of the waste heat temperature is advantageous for co-generation systems in which the heat generated by the fuel cells are recycled.

Room temperature molten salts (RTMSs, also called room temperature ionic liquids, RTILs) are liquid at room temperature without the need for a solvent. RTMSs have attracted much attention for applications in electrochemical devices and as reaction media because of their unique properties, including non-volatility, non-flammability and wide liquid-state temperature range (1-4). Moisture-stable RTMSs of the 1-ethyl-3-methylimidazolium cation (EMIm ${ }^{+}$, shown in Fig. 1) combined with $\mathrm{BF}_{4}^{-}$and $\mathrm{CF}_{3} \mathrm{SO}_{3}{ }^{-}$were first reported in $1992(5,6)$. Subsequently, various air-stable RTMSs have 
been synthesized using organic cations and fluoro-anions (7-9). There are a few previous studies on the applications of RTMSs to fuel cells. Tertiary ammonium RTMSs prepared by combinations of various organic tertiary amines and [bis(trifluoromethyl)sulonyl]imide, $\mathrm{HN}\left(\mathrm{SO}_{2} \mathrm{CF}_{3}\right)_{2}$, were demonstrated as electrolytes for fuel cells (10). A detailed study on the combination of imidazole and $\mathrm{HN}\left(\mathrm{SO}_{2} \mathrm{CF}_{3}\right)_{2}$ has been reported, wherein a proton was transferred via hopping among the ammonium cations (11). Fuel cell systems of quaternary ammonium RTMSs such as 1-butyl-3-methylimidazolium tetrafluoroborate $\left(\mathrm{BMImBF}_{4}\right)$ and hexafluorophosphate $\left(\mathrm{BMImPF}_{6}\right)$ were also reported recently (12). Since there is no species-carrying hydrogen or oxygen in these salts, hydrogen is considered to be carried via oxonium cations formed by the hydrolysis of the salts by water contaminated before the start of cell operation and/or formed by the cell reaction during the operation.

Over the last five years, we have reported a series of RTMSs of alkylimidazolium, alkylpyrrolidinium and alkylpiperidinium, combined with fluorohydrogenate anions $\left((\mathrm{HF})_{n} \mathrm{~F}^{-}\right)$(13-16). These RTMSs possess the same vacuum-stable composition $(\text { cation })^{+}(\mathrm{HF})_{2.3} \mathrm{~F}^{-}$at room temperature as well as high conductivities. It has been clarified that at this composition, the liquids are composed of the corresponding organic cation and two kinds of fluorohydrogenate anions, $(\mathrm{HF})_{2} \mathrm{~F}^{-}$and $(\mathrm{HF})_{3} \mathrm{~F}^{-}$as shown in Fig. 
$1(17,18)$. On the other hand, anionic components of HF-deficient salt, EMIm(HF) $)_{1.3} \mathrm{~F}$ for example, are $(\mathrm{HF}) \mathrm{F}^{-}$and $(\mathrm{HF})_{2} \mathrm{~F}^{-}$. Among the RTMSs of this kind, EMIm(HF) ${ }_{2.3} \mathrm{~F}$ exhibits the highest ionic conductivity of $100 \mathrm{mS} \mathrm{cm}^{-1}$ (15), comparable to the conductivity of $0.1 \mathrm{M} \mathrm{KCl}$ aqueous solution. In the present study, fuel cells based on the novel concept of fluorohydrogenate conduction in $\operatorname{EMIm}(\mathrm{HF})_{2.3} \mathrm{~F}$ and $\mathrm{EMIm}(\mathrm{HF})_{1.3} \mathrm{~F}$ RTMSs were explored. As described above, $\mathrm{EMIm}(\mathrm{HF})_{2.3} \mathrm{~F}$ is vacuum stable at $298 \mathrm{~K}$ but slowly liberates $\mathrm{HF}$ at elevated temperatures. $\mathrm{EMIm}(\mathrm{HF})_{1.3} \mathrm{~F}$ is the vacuum stable composition at $373 \mathrm{~K}$ and was used for the experiments performed at this temperature.

\section{Experimental}

Volatile materials were handled in a stainless vacuum line constructed of SUS316 stainless steal and PFA (tetrafluoroethylene-perfluoroalkylvinylether-copolymer). $\mathrm{EMIm}(\mathrm{HF})_{2.3} \mathrm{~F}$ was prepared according to the previous report (15). $\mathrm{EMIm}(\mathrm{HF})_{1.3} \mathrm{~F}$ was prepared by removing $\mathrm{HF}$ from $\mathrm{EMIm}(\mathrm{HF})_{2.3} \mathrm{~F}$ at $373 \mathrm{~K}$. All the experiments were performed using a U-shaped cell made of PFA wherein Pt-black gas electrodes were partially immersed. All the potentials obtained were referenced to the RHE potential. Electrochemical measurements were performed with the aid of a Hokuto Denko HZ-3000 electrochemical measurement system. 


\section{Results and Discussion}

The principle of the present fuel cell of EMIm(HF $)_{2.3} \mathrm{~F}$ electrolyte is shown in Fig. 2.

The cathode, anode and total reactions for the EMIm(HF) $)_{2.3} \mathrm{~F}$ fuel cell are described below:

Cathode: $1 / 2 \mathrm{O}_{2}+6(\mathrm{HF})_{3} \mathrm{~F}^{-}+2 \mathrm{e}^{-} \rightarrow \mathrm{H}_{2} \mathrm{O}+8(\mathrm{HF})_{2} \mathrm{~F}^{-}$

Anode: $\mathrm{H}_{2}+8(\mathrm{HF})_{2} \mathrm{~F}^{-} \rightarrow 6(\mathrm{HF})_{3} \mathrm{~F}^{-}+2 \mathrm{e}^{-}$

Total: $1 / 2 \mathrm{O}_{2}+\mathrm{H}_{2} \rightarrow \mathrm{H}_{2} \mathrm{O}$

On the other hand, the electrode reactions for the $\mathrm{EMIm}(\mathrm{HF})_{1.3} \mathrm{~F}$ fuel cell are given as follows:

Cathode: $1 / 2 \mathrm{O}_{2}+4(\mathrm{HF})_{2} \mathrm{~F}^{-}+2 \mathrm{e}^{-} \rightarrow \mathrm{H}_{2} \mathrm{O}+6(\mathrm{HF}) \mathrm{F}^{-}$

Anode: $\mathrm{H}_{2}+6(\mathrm{HF}) \mathrm{F}^{-} \rightarrow 4(\mathrm{HF})_{2} \mathrm{~F}^{-}+2 \mathrm{e}^{-}$

Total: $1 / 2 \mathrm{O}_{2}+\mathrm{H}_{2} \rightarrow \mathrm{H}_{2} \mathrm{O}$

These fuel cells do not require water supply for the electrode reaction or humidification of the electrolyte. 
Fluorohydrogenate salts such as KF- $n \mathrm{HF}, \mathrm{CsF}-n \mathrm{HF}$ and alkylammonium fluoride- $n \mathrm{HF}$ have been known for a long time (19-22). The melting points of CsF- $n \mathrm{HF}$ $(2<n<2.5)$ are lower than $298 \mathrm{~K}(20)$. The KF- $n \mathrm{HF}$ system is well known as an electrolyte for the electrolytic synthesis of elemental fluorine (23). It is known that $(\mathrm{HF})_{n} \mathrm{~F}^{-}$anions present in these systems are electrochemically active against $\mathrm{H}_{2}$ gas, with the $\mathrm{H}_{2}-\mathrm{Pt}$ gas electrode being used as a reference electrode for electrochemical measurements in these salts $(24,25)$. However, these salts have not been applied as electrolytes in fuel cells mainly due to the difficulty in handling HF liberated from the salts. These salts are not vacuum stable. In other words, they exhibits detectable HF-dissociation pressures at ambient conditions. On the other hand, it has been found that fluorohydrogenate salts based on cyclic ammonium cations, alkylimidazolium, alkylpyrrolidinium and alkylpiperidinium, possess negligibly small HF-dissociation pressures at ambient conditions (13-16).

Figure 3 shows the open circuit voltage $(\mathrm{OCV})$ of the $\operatorname{EMIm}(\mathrm{HF})_{2.3} \mathrm{~F}$ fuel cell at 298 $\mathrm{K}$. The OCV observed was approximately $1.1 \mathrm{~V}$ and stable during the measurement conducted for over 18 hours. In the case of $\operatorname{EMIm}(\mathrm{HF})_{1.3} \mathrm{~F}$, the OCV was $1.10 \mathrm{~V}$ at 298 $\mathrm{K}$ and $1.01 \mathrm{~V}$ at $373 \mathrm{~K}$. The results of the Nernstian plot for $\mathrm{H}_{2}$ electrodes in $\mathrm{EMIm}(\mathrm{HF})_{2.3} \mathrm{~F}$ at $298 \mathrm{~K}$ (here, partial pressure of $\mathrm{H}_{2}$ vs. electrode potential) agrees with 
the proposed two-electron reaction (2). However, the slope of the plot for the $\mathrm{O}_{2}$ cathode reaction does not coincide with that for the two-electron reaction (1). This type of disagreement is often observed for $\mathrm{O}_{2}$ gas electrodes in various electrolytes, which is considered to be caused by the difficulty for the reaction to achieve an equilibrium state at the $\mathrm{O}_{2}$ electrodes.

Figure 4 shows potentiostatic polarization curves of the $\mathrm{H}_{2}$ anode (a) and the $\mathrm{O}_{2}$ cathode (b) in EMIm(HF) $)_{2.3} \mathrm{~F}$ at $298 \mathrm{~K}, \mathrm{EMIm}(\mathrm{HF})_{1.3} \mathrm{~F}$ at $298 \mathrm{~K}$, and $\mathrm{EMIm}(\mathrm{HF})_{1.3} \mathrm{~F}$ at $373 \mathrm{~K}$. For comparison, the data obtained for $30 \mathrm{wt} \% \mathrm{KOH}$ aqueous solution using the same cell are also shown in the same figure. At $298 \mathrm{~K}$, the polarization behavior of the $\mathrm{H}_{2}$ anode in EMIm(HF) ${ }_{2.3} \mathrm{~F}$ is superior to that in the $\mathrm{KOH}$ solution over the measured range. In the case of the $\mathrm{O}_{2}$ cathode, the current observed for the $\mathrm{KOH}$ solution is small above $0.8 \mathrm{~V}$ but increases sharply below $0.8 \mathrm{~V}$. On the other hand, the current for $\mathrm{EMIm}(\mathrm{HF})_{2.3} \mathrm{~F}$ increases gradually with the negative potential shift from the rest potential. Both the anode and cathode currents observed in $\operatorname{EMIm}(\mathrm{HF})_{1.3} \mathrm{~F}$ were significantly decreased compared to that found for $\mathrm{EMIm}(\mathrm{HF})_{2.3} \mathrm{~F}$. The electrode reactions described above suggest that both the cathode and anode reactions involve cleavage and formation of $\mathrm{FH}-\mathrm{F}^{-}$bonds. Anionic species in $\mathrm{EMIm}(\mathrm{HF})_{1.3} \mathrm{~F}$ are $\mathrm{FHF}^{-}$ and $(\mathrm{HF})_{2} \mathrm{~F}^{-}$. If the rearrangement of $(\mathrm{FH})_{n}-\mathrm{F}$ bonds are rate-determining step in the 
electrode reactions, overpotentials in $\mathrm{EMIm}(\mathrm{HF})_{1.3} \mathrm{~F}$ would become higher than those in $\mathrm{EMIm}(\mathrm{HF})_{2.3} \mathrm{~F}$ due to the stronger $(\mathrm{FH})_{n}-\mathrm{F}$ bonds in $\mathrm{EMIm}(\mathrm{HF})_{1.3} \mathrm{~F}$. However, the polarization behavior for both the electrodes in $\mathrm{EMIm}(\mathrm{HF})_{1.3} \mathrm{~F}$ is drastically improved by elevating the operating temperature from $298 \mathrm{~K}$ to $373 \mathrm{~K}$ as shown in Fig. 4 . This is due to the faster electrode reactions activated at the higher temperature which is an advantage of the cell operation using this electrolyte.

Polarization behavior was also investigated using $\mathrm{EMIm}(\mathrm{HF})_{1.3} \mathrm{~F}$ and $\mathrm{EMIm}(\mathrm{HF})_{2.3} \mathrm{~F}$ containing water. No significant change was observed even for the electrolyte that was deliberately wetted. Only the water evaporates, without being accompanied by HF, when water is added to $\mathrm{EMIm}(\mathrm{HF})_{1.3} \mathrm{~F}$ at $373 \mathrm{~K}$. Consequently, water formed by the cathode reaction does not affect the cell performance under the described conditions. These observations support that the electrode reactions proposed above, where water originated ionic species such as $\mathrm{H}_{3} \mathrm{O}^{+}$are not involved.

In all the cases in the present study, the cathodic current was significantly smaller than the anodic current, as in the case of $30 \mathrm{wt} \% \mathrm{KOH}$ solution. Improvement of catalytic activity of the $\mathrm{O}_{2}$ gas cathode is a major task in the next step, similar to other fuel cells of this kind.

The high conductivity of $\mathrm{EMIm}(\mathrm{HF})_{n} \mathrm{~F}$ is advantageous for reducing the internal 
resistance of electrochemical devices. We have reported polymer composite electrolytes consisting of poly-2-hydroxyethyl methacrylate and EMIm(HF) ${ }_{2.3} \mathrm{~F}(26)$. The composite electrolyte containing $60 \mathrm{~mol} \% \mathrm{EMIm}(\mathrm{HF})_{2.3} \mathrm{~F}$ exhibits the highest conductivity of 23 $\mathrm{mS} \mathrm{cm}{ }^{-1}$ at $300 \mathrm{~K}$. PEFCs using such composite electrolytes containing EMIm(HF ${ }_{n} \mathrm{~F}$ or a membrane impregnated with $\mathrm{EMIm}(\mathrm{HF})_{n} \mathrm{~F}$ are interesting systems as are fuel cells using $\mathrm{EMIm}(\mathrm{HF})_{n} \mathrm{~F}$ ionic liquid as a neat liquid electrolyte. 


\section{References}

(1) T. Welton, Chem. Rev. 99, 2071 (1999).

(2) K. R. Seddon, J. Chem. Technol. Biotechnol. 68, 351 (1997).

(3) P. Wasserscheid, W. Kein, Angew. Chem. Int. Ed. 39, 3772 (2000).

(4) R. Hagiwara, Y. Ito, J. Fluorine Chem. 105, 221 (2000).

(5) J. S. Wilkes, M. J. Zaworotko, J. Chem. Soc., Chem. Commun. 1992, 965.

(6) E. I. Cooper, E. J. M. O’Sullivan, Proceedings of the 8th International Symposium on Molten Salts; The Electrochemical Society: Pennington, NJ, 1992; Proceeding Vol. 92-16, p 386.

(7) J. Fuller, R. T. Carlin, H. C. De Long, D. Haworth, J. Chem. Soc., Chem. Commun. 1994, 299

(8) P. Bonhôte, A. -P. Dias, M. Armand, N. Papageorgiou, K. Kalyanasundaram, M. Grätzel, Inorg. Chem. 35, 1168 (1996).

(9) K. Matsumoto, R. Hagiwara, R.Yoshida, Y. Ito, Z. Mazej, P. Benkič, B. Žemva, O. Tamada, H. Yoshino, S. Matsubara, Dalton Transactions 2004, 144.

(10) Md. A. B. H. Susan, A. Noda, S. Mitsushima, M. Watanabe, Chem. Commun. 2003, 938. 
(11) A. Noda, Md. A. B. H. Susan, K. Kudo, S. Mitsushima, K. Hayamizu, M. Watanabe, J. Phys. Chem. B 107, 4024 (2003).

(12) R. F. de Souza, J. C. Padilha, R. S. Gonçalves, J. Dupont, Electrochem. Commun. 5, $728(2003)$.

(13) R. Hagiwara, T. Hirashige, T. Tsuda, Y. Ito, J. Fluorine Chem. 99, 1 (1999).

(14) R. Hagiwara, T. Hirashige, T. Tsuda, Y. Ito, J. Electrochem. Soc. 149, D1 (2002).

(15) R. Hagiwara, K. Matsumoto, Y. Nakamori, T. Tsuda, Y. Ito, H. Matsumoto and K. Momota, J. Electrochem. Soc. 150, D195 (2003).

(16) K. Matsumoto, R. Hagiwara, Y. Ito, Electrochem. Sol. State Lett., 7, E41 (2004).

(17) J. H. Clark, J. Emsley, D. J. Jones, R. E. Overrill, J. Chem. Soc., Dalton Trans. 1981, 1219

(18) T. v. Rosenvinge, M. Parrinello, M. L. Klein, J. Chem. Phys. 107, 8013 (1997).

(19) G. H. Cady, J. Am. Chem. Soc. 56, 1431 (1934).

(20) R. V. Winsor, G. H. Cady, J. Am. Chem. Soc. 701500 (1948).

(21) W. D. Chandler, K. E. Johnson, J. L. E. Campbell, Inorg. Chem. 34, 4943 (1995).

(22) I. Gennick, K. M. Harmon, M. M. Potvin, Inorg. Chem. 16, 2033 (1977).

(23) H. Groult, D. Devilliers, F. Lantelme, J.P. Caire, M. Combel, F. Nicolas, J. Electrochem. Soc. 149, E485 (2002). 
(24) S. Pizzini, G. Sternhem, G. B. Barbi, Electrochim. Acta 8, 227 (1963).

(25) S. Pizzini, A. Magistris, Electrochim. Acta 9, 1189 (1964).

(26) T. Tsuda, T. Nohira, Y. Nakamori, K. Matsumoto, R. Hagiwara, Y. Ito, Solid State

Ionics 149, 295 (2002). 


\section{Figure captions}

Fig. 1 Molecular structures of (a) 1-ethyl-3-methylimidazolium cation $\left(\right.$ EMIm $\left.^{+}\right)$, (b)

$(\mathrm{HF})_{2} \mathrm{~F}^{-}$, and (c) $(\mathrm{HF})_{3} \mathrm{~F}^{-}$.

Fig. 2 Principle of a fuel cell based on fluorohydrogenate conduction.

Fig. 3 Open circuit voltage $(\mathrm{OCV})$ between $\mathrm{H}_{2}$ and $\mathrm{O}_{2}$ gas electrodes in EMIm(HF) ${ }_{2.3} \mathrm{~F}$ at $298 \mathrm{~K}$.

Fig. 4 Polarization behavior of (a) $\mathrm{H}_{2}$ and (b) $\mathrm{O}_{2}$ electrodes in $\mathrm{EMIm}(\mathrm{HF})_{2.3} \mathrm{~F}$ at $298 \mathrm{~K}$,

$\mathrm{EMIm}(\mathrm{HF})_{1.3} \mathrm{~F}$ at $298 \mathrm{~K}, \mathrm{EMIm}(\mathrm{HF})_{1.3} \mathrm{~F}$ at $373 \mathrm{~K}$, and $30 \mathrm{wt} \% \mathrm{KOH}$ solution. 


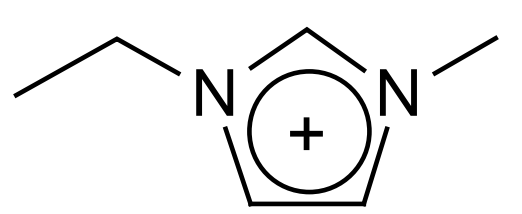

(a)

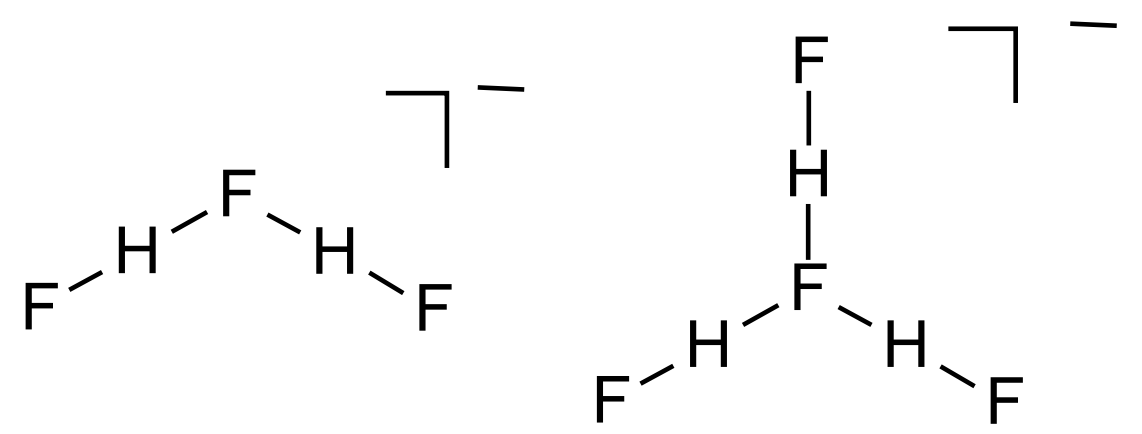

(b)

(c)

Figure 1 


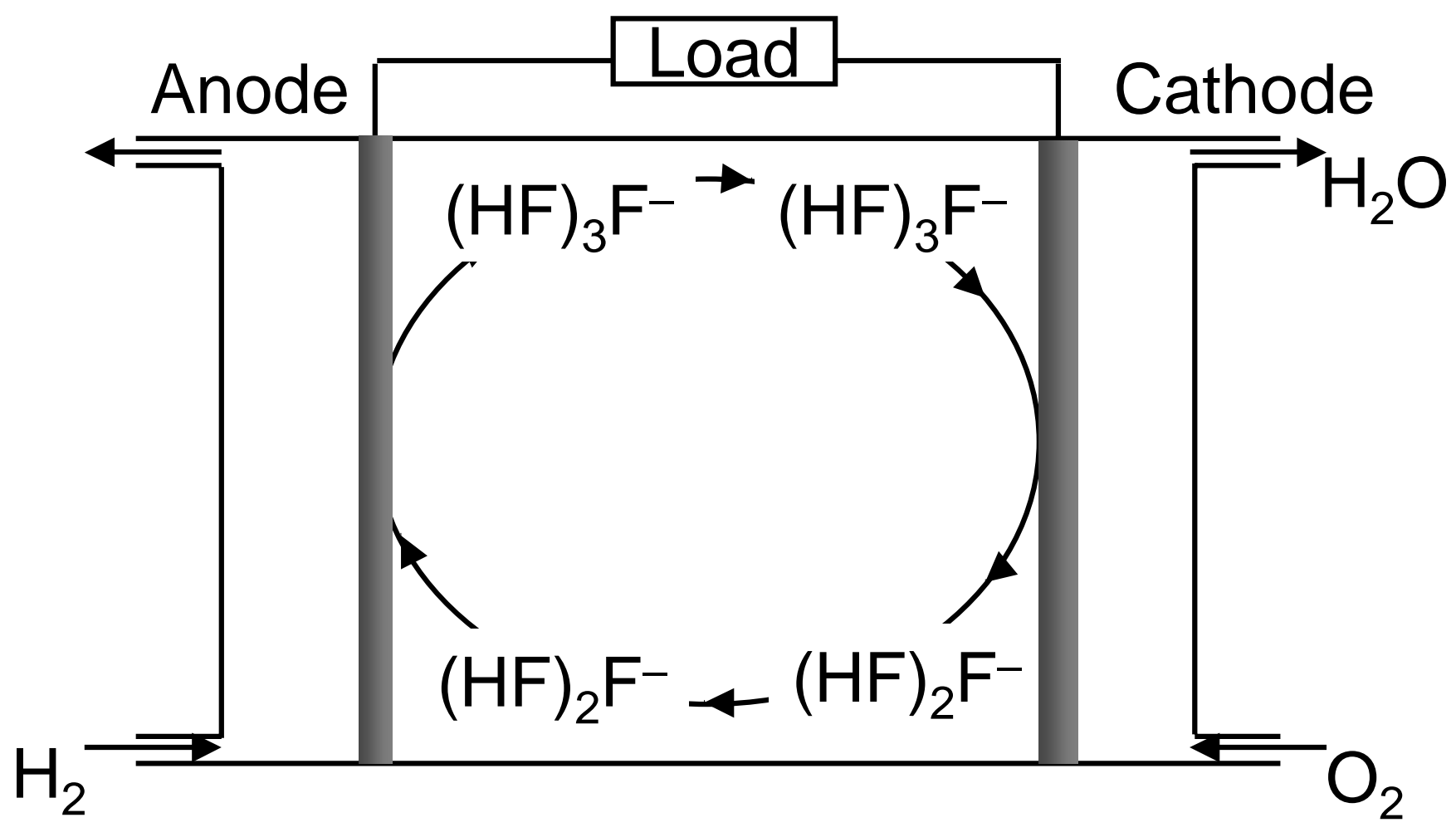

Figure 2 


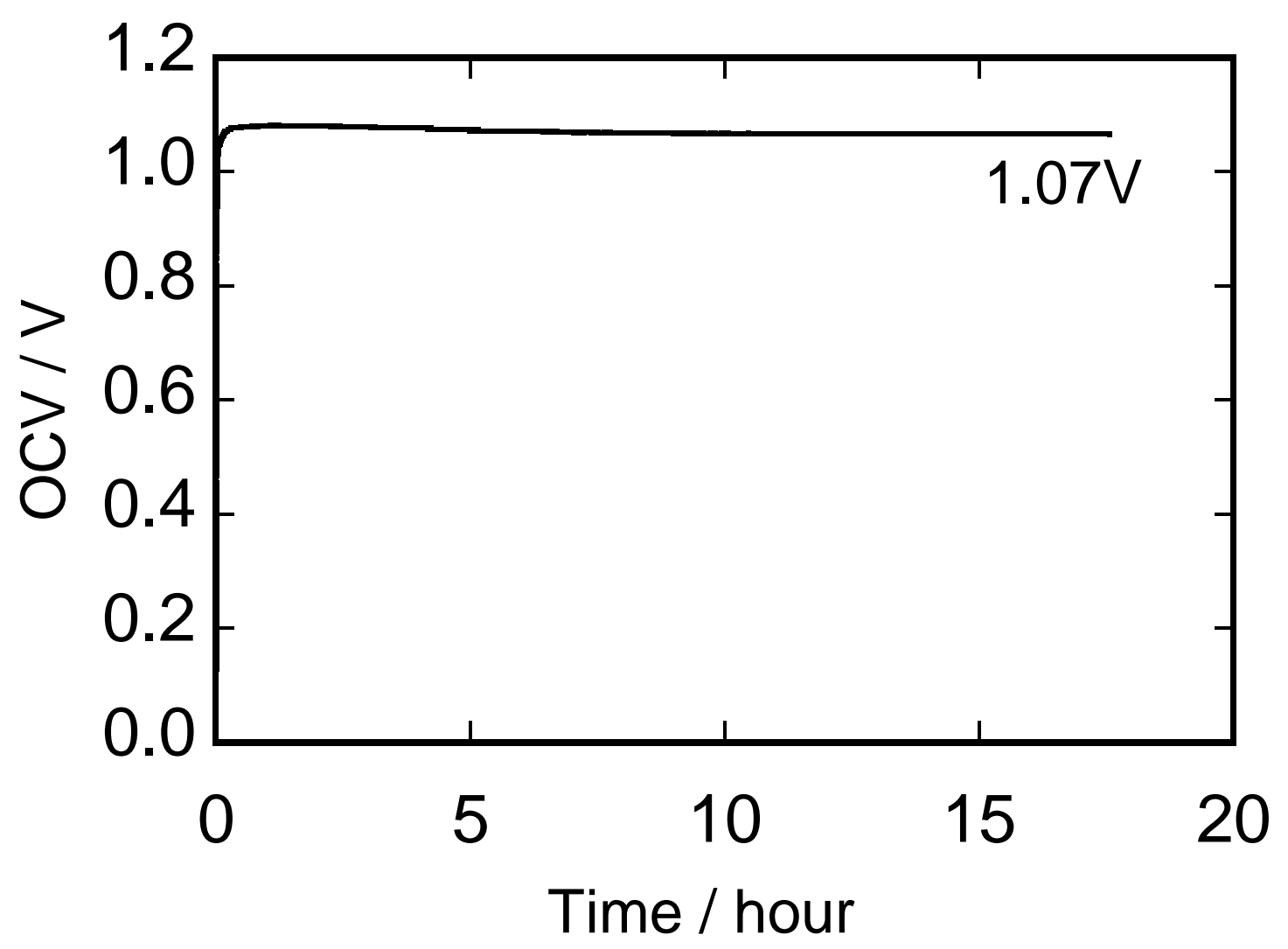

Figure 3 

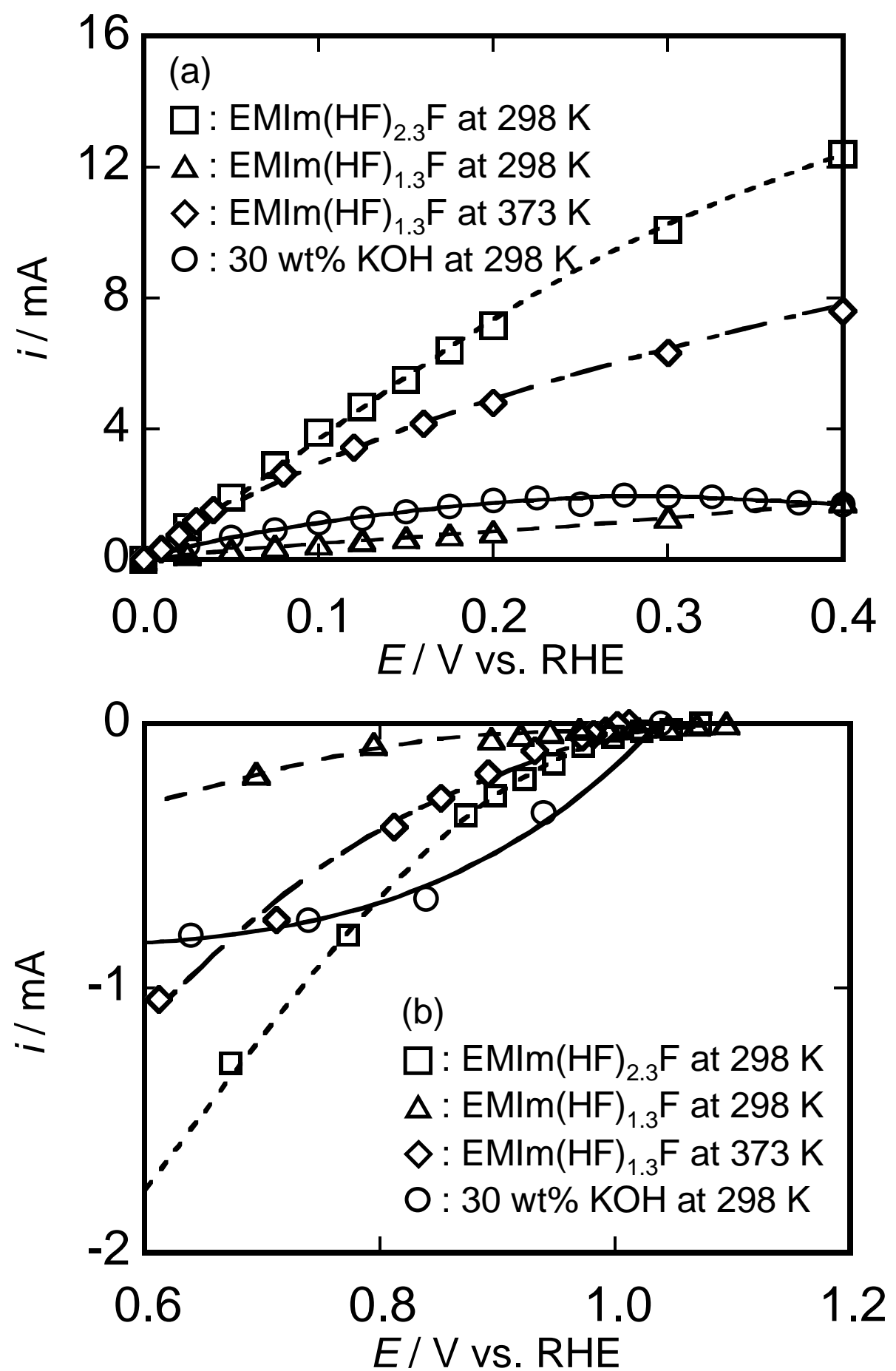

Figure 4 